\title{
Code-switching in online communication of the Russian migrants in Germany
}

\author{
Aleksandr Simanychev \\ Student \\ Russian State University for the \\ Humanities, Moscow, Russia \\ simaitunes@gmail.com
}

\begin{abstract}
In this paper, I built a grabber for posts from Russian migrants in the German community on the social network "Вконтакте" (vk.com) to retrieve cases of Russian-German code-switching. After manual disambiguation I compiled a small corpus of 810 posts, including 425 different borrowed words, collocations, and clauses that I used to classify the cases of code-switching and to prove the hypothesis of the absence of non-functional code-switching in written speech. Also, the hypotheses put forward by Brehmer (2007) on the quality of German influence on the Russian language of immigrants were both partially refuted and confirmed.
\end{abstract}

Keywords: Code-switching, Social media, loanwords, Russian, German, language of migrants

DOI: $10.28995 / 2075-7182-2021-20-1197-1205$

\section{Переключение кода в онлайн коммуникации русскоязычных мигрантов в Германии}

\author{
Александр Александрович Симанычев \\ Студент \\ Российский Государственный Гуманитарный \\ Университет, Москва, Россия \\ simaitunes@gmail.com
}

\begin{abstract}
Аннотация
Для данного исследования мной был построен «граббер» публикаций русскоязычных мигрантов в немецком сообществе социальной сети «Вконтакте» (vk.com) для извлечения случаев русско-немецкого переключения кодов. После ручного снятия омонимии я собрал небольшой корпус из 810 публикаций, включающих в себя 425 различных заимствованных слов, словосочетаний и предложений, которые были использованы мной для классификации случаев переключения кода и для доказательства гипотезы об отсутствии нефункционального переключения кода в письменной речи. Кроме того, выдвинутые Бремером (2007) гипотезы о силе влияния немецкого языка на русский язык у мигрантов были частично опровергнуты, частично подтверждены.

Ключевые слова: Переключение кода, социальные сети, заимствования, русский язык, немецкий язык, язык мигрантов
\end{abstract}

\section{Introduction}

The purpose of this work is to collect the most frequent German words in the Russian speech of Russian immigrants in Germany, to find and describe as much as possible the cases of code-switching (CS) in their speech, and to classify them according to the type of CS.

The subject of this work is code-switching in the speech of Russian-speaking immigrants in Germany, their frequency, and the language levels that are affected by CS. 
No article on this subject is complete without discussing whether one-word insertions are CS. This happens due to the complexity of the definition, and hence there is a variability of approaches to understanding and describing this phenomenon. To demonstrate my approach to this topic, I will review several key works.

The approach of Sankoff and Poplack (1981) in their studies of CS does not consider single word insertions as CS. There were claims that the single word follows the principle of the matrix language (hereafter ML). These researchers considered phrasal insertions as an example of CS rather than single word insertions. In contrast to them, in the second approach, other researchers like Myers-Scotton (1993) and Heller (1988) contested that borrowing and CS should not be considered as two distinct elements. In point of fact, both of these phenomena are "part of the same developmental continuum" (MyersScotton, 1993: 163).

According to F. Grosjean (1995), if the insertion from the included language, in my case from German, is phonetically formed in the matrix language in the same way as in the embedded one, then this is CS. If it is pronounced with the phonetics of a matrix language, then it is a loanword. But many migrants, despite their high competence in the language, have an accent, and therefore it makes sense to remain not within the framework of an approach that distinguishes these two terms, but to consider them as a single extended continuum.

Myers-Scotton (2006: 254) argued that "[ $\mathrm{t}]$ here is a continuum of embedded language (hereafter EL) elements in bilingual clauses, with single words as one end point and full phrases as the other. Further, many singly occurring words that are code-switches could (and do) become established borrowings if they are adopted by trend-setters." (Marzieh Hadei, 2016)

In this paper, I will assume that all cases of insertions from the embedded language into the matrix language are CS. Despite the large Russian-speaking population in Germany, it is still too early to talk about a common mental lexicon, so the insertions have not had enough time to become part of it, as it was evidenced by a large number of metalinguistic comments on the acceptability of certain constructions with German words. The presence of variation in spelling and morphological constructions also confirms my point of view.

Brehmer (2007) in his work devoted to the so-called Qwelja, the language of the Russian-speaking minority in Germany, relies exclusively on oral speech. In his article, he also raises the topic of what he calls borrowings and what in my work relates to CS. Brehmer emphasizes that German borrowings are integrated into the morphology of the Russian language. Thus, German nouns ending with a consonant most often acquire the masculine gender, and those ending with vowel $-e$ acquire the feminine gender, regardless of what gender the noun had in German. As for the neuter gender, according to Brehmer, it does not tend to appear in the borrowings.

Other works noted examples of Russian-German CS, but, as far as I am concerned, there is no research focused exclusively on this material, not to mention quantitative research with the use of machine methods.

Speaking about theoretical point of view, this article shows counter-arguments to Brehmer's hypothesis as his ideas were based on observation, and not on corpus methods.

To collect a corpus, I found a community page in the biggest Russian social network "ВКонтакте" (vk.com) called "Подслушано Германия" ‘Overheard Germany' (41332 subscribers by 29.06.2020), which was and is the largest of all the eligible active public pages for Russian migrants in Germany nowadays. About 5 posts are published per day, which receive 10 to 100 comments each. The vast majority of posts are authored, and the group is not a news aggregator. I wrote a "grabber" of posts in Python (see 1. Appendix) specifically for this work, a program that extracts posts from the source according to certain parameters. In my case, these were all publications (posts andcomments), which included the word forms of the required lexeme.

In order to make a primary list of words that would be searched for, a survey was conducted among 10 Russian migrants living in Germany for different periods of time (3-15 years) and belonging to different social classes. The informants were asked to recall which German insertions occur in their Russian speech, then to evaluate the acceptability of sentences generated by other informants, and finally to evaluate how frequently they use these words on a scale of never / sometimes / often. The data obtained after the search performed by the program was automatically written out in a CSV table. The total number of the entries was 750 . 
Since it is not possible to distinguish the code switching automatically due to the lack of an established Cyrillic transliteration of German words, all the 750 entries were reviewed manually. As a result, about 70 posts that turned out to be false positive were removed. For example, these contained homographs (Russian те́рмин 'term' and German loanword терми́н 'appointment' $(<$ Termin)). The rest of the 68 uses were manually confirmed as cases of code-switching. A large number of one-time occurrences of previously unaccounted for German words written in both the Cyrillic and Latin alphabet expanded the original list of search words. After that, a secondary search was conducted for new words, but it brought no more than 60 additional publications.

After that, I used PyMorphy2 library (see 2. Appendix) to automatically predict their initial form according to the most common patterns of the Russian morphology: в aмme - avm 'state institution', моббили - моббить 'humiliate, mob'). In cases where this could not be done automatically (миту $*_{\text {Mum }}$ ) (about $5 \%$ ), the initial form was corrected manually (мumy-мuma 'rent').

The second part of the program was responsible for counting lemmas. I combined all the different variants of the Cyrillic spelling of the same word, choosing the most frequent variant as its representative and adding to it the number of other variants (арбайзамта (sic!) - арбайтсамта 'employment center'), while writing in Latin script was considered separately, in order to distinguish between marked and unmarked PC. The unification under one lemma helped to avoid underestimating of the results due to typos (ладесамта - ландесамта 'city department, city hall', пусбильдунг - аусбильдунг 'education').

Summing up my final calculations, I received 425 unique words/phrases. However, 322 of them were used only once. I will start with the most frequent ones (see 1. Diagram) and explain why they are located at the top of the list, and others are not.

\section{Lexics and orthography}

In the top twenty, I found cases of prototypical referential function of CS - the case when the speakers switch their language either because they are not able to find the right word, or the word does not exist [Appel, Muysken 1987]: хаусмайстер (German: Hausmeister) (7th place, 44 uses) 'the person who is responsible for managing the house and keeping order' (in all senses of the word: both as a janitor and as a senior at the entrance); $\mathrm{amm}$ (German: $\mathrm{Amt}$ ) (4th place, 85 uses) 'state institution' (depending on the additional root, it can be designated as a tax inspectorate - финани амт / финанцамт (German: finanzamt), and the employment center — арбайтс амт / арбайтсамт (German: Arbeitsamt); абитур (German: Abitur) (15th place, 10 uses) 'German high school graduation certificate'; терми́н (German: Termin) (6th place, 69 uses) 'appointment scheduled for a certain time'; джобиентр (German: Jobcenter) (12th place, 12 uses) 'employment center' (exclusively for manual labor); бadez (German BAföG-Bundesausbildungsförderungsgesetz) (17th place, 9 uses) 'German scholarship for students'; праксис (German: Praxis) (13th place, 12 uses) 'medical practice'. All these words have no Russian equivalents that could replace German words without using cumbersome descriptive constructions.

Let us take a look at аусбильдунг (German: Ausbildung) (1st place, 135 uses), as it is the most prominent representative. In Russian, there is no suitable equivalent, since there is no corresponding reality. Despite the fact that in German Ausbildung means any kind of education or learning, in Russian texts the meaning of аусбильдунг is narrower, and this word is used only in one extremely specific meaning: secondary vocational education typical for Germany, during which a person studies and works simultaneously.

The Russian language simply does not have the possibility to express this in one word, and therefore the CS is functionally caused here. The variants of semantics and contexts here are slightly different from the word образование 'education' in Russian. So, the contexts of usage are more similar to the Russian word курсы 'courses': пойти на аусбильдунг - пойти на курсы 'go to the courses', закончить аусбильдунг - закончить курсы 'finish the courses', девочки с аусбильдунга - девочки с курсов 'girls from the courses', трудности на аусбильдунге - трудности на курсах 'difficulties in the courses'. However, there are also contexts that are still closer to the word образование 'education': у меня аусбильдунг в правовой сфере - у меня образование в правовой сфере 'I have an education in law'. In some cases, a syntactic construction with a semi-auxiliary verb is even calqued from the German language: аусбильдунг делает - Ausbildung macht (1). 
(1) Катерина написала, что тем, кто делает аусбильдунг государство помогает.

'Katerina wrote that the state helps those who make courses (ausbildung).'

The spelling of Ausbildung in the Latin alphabet was found only three times, and in two of them the function of the CS was directive-metalinguistic (2). That is, the author introduced the term to those who do not know this word. Once more, Ausbildung was used together with the German adjective schulische 'scholar' (3), with which it forms a stable noun phrase, since there are two types of Ausbildung - duale (analogous to targeted training in Russia by one's company) and schulische (specialties like medicine, pedagogy, and social work). It is difficult to unequivocally interpret what caused the usage of the Latin alphabet, but I can suggest that this is a quote from an official document that the speaker remembered in this form. If this is not the case, then the answer to the question lies rather in the word schulische: since adjectives are borrowed less often than nouns (Brehmer 2007), there was a small chance of its Cyrillic spelling (in my work there was only one such case), and the word schulische is linked to the top of the noun phrase.

(2) Ausbildung это проф образование... ...аусбильдунг в Телекоме стоит больще...

'Ausbildung is a professional education... ... education (Ausbildung) in Telecom costs more...'

$$
\begin{aligned}
& \text {... Многие конечно на альтенпфлеге, но при желании можно было выбить [место - } \\
& \text { А.С.] на любое schulische Ausbildung... } \\
& \text {... Many, of course, are in elderly care (Altenpflege), but if you want you could get [a place- } \\
& \text { A. S.] at some school-based education (schulische Ausbildung) ...' }
\end{aligned}
$$

The situation is different with such words as конто (German: Konto) (3rd place, 104 uses) 'bank account'; бевербунг (German: Bewerbung) (2nd place, 109 uses) 'application for work/study, motivation letter'; мита (German: Miete) (5th place, 74 uses) 'rent'; анмельдунг (German: Anmeldung) (8th place, 18 uses) 'registration at the place of residence'; флюхтлинг (German: Flüchtling) (9th place, 18 uses) 'refugee' (more often from the East); соииаль (German: Sozial) (11th place, 13 uses) 'allowance, cash payment'; аусвайс (German: Ausweis) (16th place, 10 uses) 'passport'. The appearance of these words in the top twenty is due to the current realities for migrants and residents of Germany in general, as well as due to bureaucratic issues. This vocabulary occurs even more in the speech of those people who moved to Germany as students, and therefore they did not have enough time to learn this vocabulary in Russia, so German words come to their mind more often as more frequently used with the exception of the word аусвайс, which, however, is used only when meaning the German ID-card. In this group of words, the Latin alphabet spelling is very rare. Similarly, in the example (4), the author highlights the key phrases in Latin spelling, leaving the word бевербунг in the Cyrillic spelling, marking this as less important. As for бевербунг in (5), it is a direct quote.

... писать бевербунги на учёбу на Altenpfleger во все возможные места.

'to write some applications (Bewerbung) for the study on elderly care specialist (Altenpfleger) in all possible places.

$$
\begin{aligned}
& \text {...Но бевербунг применяют также к мотивачионному письму. Наличие же наверху пи- } \\
& \text { шут Веwerbung zиr/als блабла как заглавие, а не Motivationsschreiben. } \\
& \text { '... But the application is also attached to the motivational letter. At the top is written as the title } \\
& \text { that it is an application for (Bewerbung zum / als) and etc., and not motivational letter (Motiva- } \\
& \text { tionsschreiben).' }
\end{aligned}
$$

Now let us get down to those words and phrases that occurred only once in my corpus (see Diagrams 2. and 3.). An important detail is that 193 of them are written in Latin and 129 in Cyrillic, in contrast to the most frequent ones among which there were only 30 in Latin and 73 in Cyrillic. One can immediately note how diverse the vocabulary is here. In addition to nouns and adjectives even whole clauses appear: иммер зо мит андерен ширахен (German: immer so mit anderen Sprachen) 'always so with other languages'; гезеилих (German: gesetzlich) 'legitimate'; ganz ok 'quite acceptable' 
Since the written transmission of CS in the majority of cases is mainly spoken language that was written down and not vice versa, I may be sure that this is due to the lack of a clear spelling system. Sometimes I may suggest that it is a deliberate distortion of the spelling like льбинслауф (German: Lebenslauf) 'summary'. Such orthographical games are not new and have existed on the Russian Internet since the beginning of the 2000's (Krongauz 2013).

There is also a problem with the endings -ер and -op in the word бератор/бератер (German: Berater) 'consultant' $(6,7)$. This is due to the fact that in the Russian language there is a large number of words with -amop ending, denoting an actor, while there is no -amep ending. So, here it is the choice between folk etymology and accurate transliteration.

...больше не спрашивали мужского бератера

'... asked no more for male consultant (Berater)'

\section{...Это даже не штойербератор. \\ '...He's not even taxes consultant (Steuerberater)'}

It is also worth mentioning that in the German language there is a rule that all nouns should be written with a first capital letter. With the switching to the Russian letters, there is no consistency observed (8, $9,10)$. The author can use both options in adjacent sentences $(8)$. In the vast majority of cases, words written in Cyrillic begin with a lowercase letter, but German words written in Latin are always transmitted with a capital letter (10), even though in German online communication the entire text is often written in lowercase letters.

(8) ...Когда Бевербунги пишут по всем известным шаблоном... Хороший бевербунг это и ecmb $-\ldots$

'...When the application (Bewerbung) is written according to all known patterns... A good application (Bewerbung) is what it is...'

(9) ...какой то Амт ей еще приплачивал.

'some state institution (Amt) also paid her extra.'

(10) В бафёг амта говорят что я сама виновата... А в Jugendamt говорят что это не их проблемиl.

'In bafeg state institution (BAFÖG Amt) they say that I am guilty... And in the state institution of youth (Jugendamt) they say that this is not their problem.'

Functional CS is characterized by "flagged code-switching" (Arnfast, 2003): it is expressed in comments, repetitions, or translations (11). The use of quotation marks in written speech also can be considered 'flagging' (12).

(11) К К занятым сотрудникам всевозможных амтов (учреждений)...

'To employees of various state institutions (Amt) (institutions)...'

(12) .. другой студент искал переемщика "Nachmieter" хорошей квартиры ...

'another student was looking for a renter "Nachmieter" for a good apartment'

\section{Morphology}

Now let us delve into the morphological level. The most interesting situation here is with verbs (see Table 1.). All of them, with the exception of митовать (German: mieten) 'rent', occurred only once, which means that, regardless of how I define borrowing and CS, they are a kind of the latter. I also have the verbal noun абштоерование (German: absteuеrn) 'reduction of the tax rate'.

Let us return to the nouns, and more specifically to their gender. My examples contradict what is written about the grammatical forms of borrowings in the work (Brehmer, 2007), which I mentioned in the beginning of this article. Firstly, in Brehmer's work, it is stated that borrowings do not take the neuter 
gender, whereas the word конто (German: Konto) 'account' in the vast majority of cases acquired the neuter gender, although it is also possible to find variants with a masculine or even feminine gender. In all cases, with the exception of one, конто does not decline. Also, a change of the initial form to конта $(15,17)$ instead of the more frequent конто was observed twice. I suppose that this happened due to the same pronunciation of the unstressed $o$ and $a$, while the latter is the typical ending for the feminine nouns.

(13) Хорошо, когда конто одно (nеuter)

'Good, when there is only one account (Konto)'

(14) Как мужчины и женщины относятся к общей конто... (feminine)

'What men and women think about the common account (Konto)'

(15) Значит конта настоящая (feminine)

'Then the account (Konto) is real'

(16) Если хотите бесплатный конто (masculine)

'if you want a free account (Konto)'

(17) ...получать миту просто на конту (feminine)

'to get rent (Miete) to the account (Konto)'

Secondly, considering the word праксис (German: Praxis) 'practice', Brehmer would have expected the masculine gender in this case, as the word ends in a consonant, but the examples show the opposite: in all cases, this noun acquired the feminine gender, as in German, both in Latin and Cyrillic script. It is also worth mentioning that this word is not declinable, which is quite expected for feminine words ending with a consonant.

However, morphology is not the only way to explain the choice of gender. This may be related with the relationship between a generic term and a specific instance of it. "The grammatical gender of inanimate nouns is motivated by intralinguistic factors, following the model that grammatical gender of a hypernym or an implied word effects on grammatical gender of hyponyms. (Strausov, 2006). This also applies to other examples mentioned below. ${ }^{1}$

(18) Он свою праксис открыл прямо в доме

'He opened practice (Praxis) in the house'

(19) Каждая праксис будет работать по 8 часов в день 'Every practice (Praxis) will be opened for 8 hours a day'

(20) Проситься на практику в частную Arztpraxis

'to ask to get place in private practice (Praxis)'

One more word that is important to consider while talking about gender is the word мume / мuma (German: Miete) 'rent'. There is variation in spelling here: one is closer to the German version мume and the second one is adapted suma. It is noteworthy that, regardless of the spelling, the word has a feminine gender. If Mite is spelled like мuma then it is characterized by a complete set of inflections, while мume is indeclinable.

(21) Сейчас в городах с дорогой митой

'Now in the cities with high rent (Miete)'

(22) Мита дороже

'rent (Miete) is higher'

\footnotetext{
${ }^{1}$ Благодарю рецензента №3 за данное замечание.
} 
(23) Один из городов с самой высокой мите

'One of the cities with the highest rent (Miete)'

(24) Это чисто за мите на здание

'It's only rent (Miete) for building'

The other words have the predicted gender and declension. The words "аусбильдунг" and "бевербунг", like most other abstract nouns and nouns meaning things, are declined as inanimate masculine nouns of the "table" type despite the feminine gender of the original word. It is also worth mentioning the genitive negation of the word аусбильдунг (26). The presence of CS in marginal forms may indicate a really strong proficiency in vocabulary because the author of the comment freely defines аусбильдунг as a noun with an abstract meaning.

\section{(25) Мне отказали в аусбильдунге}

'I was denied a course (Ausbildung)'

(26) Не найти аусбильдунга на акушерку

'To find no courses (Ausbildung) for an obstetrician'

(27) Что скажешь насчет бевербунга...

'What would you say about the application (Bewerbung)...'

(28) Суть сводится к бевербунгу...

'The essence comes down to the application (Bewerbung)...'

Words that signify a person хаусмайстер, флюхтлинг, бератор, полицай change according to the rules of declension of animate masculine nouns of the type "муж". It is worth mentioning that in most cases the word флюхтлинг is used with plural ending, since the refugees are always described as a single group. Also, an example of the formation of the plural in a word written in Cyrillic with the German ending -e (31) was found. This was the only case of German inflection in Cyrillic spelling that was found in my data.

\section{(29) Бегал потом к хаусмайстеру}

'He ran afterwards to the caretaker (Hausmeister)'

(30) Освобождайте квартиры для флюхтлингов

'Free up apartments for refugees (Flüchtlinge)'

(31) Раньше еще флюхтлинге не было

'There were no refugees (Flüchtlinge) before'

\section{Self-reflection}

Meng and Protassova in their work (2005) cited a part from a dialogue between two migrants where they noted that migrants adopted the possibility of CS from other migrants who had arrived earlier. I do not deny that this may be true, but it really is not the case for everyone. In particular, one of my informants had difficulties communicating with her parents even before she met one of the Russian-speaking migrants. Therefore, it is possible to assert the existence of CS that is unrelated to the borrowing from other migrants.

Despite such a widespread usage of German vocabulary in the speech of Russian-speaking migrants, attitudes towards such use are ambiguous and controversial. Further in this article are examples of both a neutral-positive attitude (32), (33), and a negative one (34), (35) are listed. These examples were taken from the posts of my corpus and demonstrate highly subjective views that are typical for naive linguistics. 
(32)

...коммуникативную функцию язык реализует в полной мере при использовании аутентичной терминологии. Для моего уха "ведомство" звучит коряво, если речь о каком-то Rathaus/Amt/Behörde etc. Для повседневной жизни "амт" прекрасно подходит.

'...language fully implements its communicative function when using authentic terminology. For me, "department" sounds clumsy when it is about some Rathaus/Amt/Behörde, etc. For everyday life, "amt" is perfectly suitable.'

(33) Некоторые слова настолько здесь употребительны, что люди предпочитают их русским аналогам. Например анмельдунг, Кюндигунг. Сказать Ауслендербехерде быстрее, чем учреждение по делам иностраниев.

'Some words are so common here that people prefer them to their Russian equivalents. For example, Anmeldung and Kündigung. To say Ausländerbehörde is faster than "a state institution for foreigners".'

(34) Вы все ещуе пытаетесь оправдать какой то нелепый "трефф"? ) Тут есть огромная разнииа: Есть заимствованные слова языка. Есть имена собственные / названия, которые можно лишь адаптировать под любой язык: Лейпциг (Ляйпщиг), Готика (Gothic, gotico) - Это все вполне допустимые для русского языка слова. И меня это никак не смущает. А теперь найдите мне хоть в одном русском словаре слово "Треф $\phi "$ ", которое обозначает встречу/фестиваль.

'Are you still trying to justify some ridiculous "treff"?) There is a huge difference here: there are borrowed words of a language. There are proper names / names that can only be adapted to any language: Leipzig (Laipzig), Gotica (Gothic, gotico) - these are all quite acceptable words for the Russian language. And they don't bother me in any way. Now find me at least in one Russian dictionary the word "Treff", which means a meeting/festival.'

(35) Люди потом общаться то не умеют и мысль свою выразить на одном из языков. В гости например русские приезжают, а местные им такие люди втирают про какие то треффы, миты, ангеботы, иуги и банхофыл.

'People then do not know how to communicate and express their thoughts in one of the languages. For example, Russians come to visit, and local people talk about some treffy (Treff), mity (Miete), angeboty (Angebot), tsugi (Zug) and banxofy (Bahnhof).'

\section{Continuation of work}

Actually, this work encouraged me to conduct additional research, which I started right after this one. As mentioned above, the community in "Вконтакте" is the largest of all the eligible active public pages nowadays. But it was not always the case. While looking for forum pages of Russian migrants in Germany, I found a big community on "LiveJournal", where there have been almost 160,000 posts and comments since 2004. I created a new grabber that downloaded all this data into my database. This vast amount data has given me the possibility to confirm or refute my hypotheses, build up bi-gramm lists for found single-word insertions. More importantly, this can show how the vocabulary and worldview of the migrants have been changing over the last 16 years. Copious amounts of information allow us to conduct quantitative and qualitative research properly.

\section{References}

[1] Anstatt T. Der Erwerb der Familiensprache: Zur Entwicklung des Russischen bei bilingualen Kindern in Deutschland. - Gogolin I., Neumann U. Streitfall Zweisprachigkeit - The Bilingualism Controversy. VS Verlag für Sozialwissenschaften. 2009.

[2] Appel R., Muysken P. Language contact and bilingualism. London and Baltimore, 1987

[3] Auer P. From codeswitching via language mixing to fused lects: toward a dynamic typology of bilingual speech. - International Journal of Bilingualism, 2009. — Vol. 3(4) - pp. 309-332

[4] Bagana J. (2010) Contact Linguistic: Interaction of Languages and Bilingualism [Kontaktnaya lingvistika: vzaimodeistvie yazykov i bilingvizm]. Moscow: Flint: Science 
[5] Brehmer B. Sprechen Sie Qwelja? Formen und Folgen russisch-deutscher Zweisprachigkeit in Deutschland. - Anstatt T. Mehrsprachigkeit bei Kindern und Erwachsenen: Erwerb, Formen, Förderung. Tübingen: Attempto Verlag, 2007. - pp. 163-186.

[6] Gardner-Chloros, P. Code-switching. Cambridge: Cambridge University, 2009

[7] Grosjean. F. A psycholinguistic approach to code-switching: the recognition of guest words by bilinguals. Milroy L. and Muysken P., One Speaker, Two Languages: Cross-Disciplinary Perspectives on Code-Switching, Cambridge: Cambridge University, 1995 - pp. 259-275

[8] Gumperz J. Discourse strategies. Cambridge: Cambridge University. 1982.

[9] Hadei M. Single Word Insertions as Code-switching or Established Borrowing? International Journal of Linguistics 8(1): 14, 2016.

[10] Kallmeyer W. and Keim I. Deutsch-türkische Kontaktvarietäten. Am Beispiel der Sprache von deutsch-türkischen Jugendlichen. - Deutsch aktuell. Einführung in die Tendenzen der deutschen Gegenwartssprache. Rome, 2004.

[11] Krongauz M.A. (2013) Self-learning manual of ,Olbanian“ [Samouchitel Olbanskogo]. Moscow: Corpus

[12] Meng K. (2001) Russlanddeutsche Sprachbiografien. Untersuchungen zur sprachlichen Integration von Aussiedlerfamilien. - Studien zur deutschen Sprache. Tübingen, Vol. 21, pp. 549

[13] Meng K./Protassova E. (2005) „Aussiedlerisch“. Deutsch-russische Sprachmischungen im Verständnis ihrer Sprecher. - Hinnenkamp, V./Meng, K.: Sprachgrenzen überspringen. Sprachliche Hybridität und polykulturelles Selbstverständnis, Tübingen

[14] Muysken P. Bilingual Speech: A Typology of Code-mixing. Cambridge: Cambridge University Press, 2000.

[15] Myers-Scotton C. Duelling Languages: Grammatical Structure in Codeswitching. Oxford: Clarendon Press, 1993.

[16] Myers-Scotton C. Jake J.L. Explaining Aspects of Codeswitching and Their Implications, — One mind, Two Languages: Bilingual Language Processing. Oxford:Blackwell, 2001. — pp. 84-116.

[17] Myers-Scotton C., Jake J.L. Testing a Model of Morpheme Classification with Language Contact Data. International Journal of Bilingualism, 2000. - Vol. 4/1, - pp. 1-8

[18] Namba, K. An overview of Myers-Scotton 's Matrix Language Frame model, 2004

[19] Poplack S. Sometimes I'll start a sentence in Spanish Y TERMINO EN ESPAÑOL: toward a typology of code-switching, 1980 - Linguistics Vol. 18, - pp. 581-618

[20] Protassova E. (2005) Multilingualism in childhood [Mnogoyazychie v detskom vozraste]. Zlatoust

[21] Riehl C.M. Code-switching in Bilinguals: Impacts of Mental Processes and Language Awareness. University of Freiburg, 2005.

[22] Sankoff, D., Poplack, S., Vanniarajan, S. The case of the nonce loan in Tamil. - Language Variation and Change, 1990 - Vol. 2 (1), - pp. 71-101

[23] Simanychev A.A. (2018) The dialect of German in Podsosnovo: consonant system and current sociolinguistic situation [Nemecky dialekt sela Podsosnovo: konsonantism I tekuschee soziolingvisticheskoe polozhenie]. Moscow

[24] Söderberg Arnfast, J. and Jørgensen, J.N. Code-switching as a communication, learning, and social negotiation strategy in first-year learners of Danish. — International Journal of Applied Linguistics, 2003 Vol. 13, - pp. 23-53

[25] Strausov V. N. (2006) Motivation and functions of grammatical gender in multi-system languages [Motivirovannost' i funkcii grammaticheskogo roda v raznosistemnyh yazykah]. Pyatigorsk 